\title{
Eucalyptus Bark Charcoal: the Influence of Carbonization Temperature in Thermal Behavior
}

\author{
Elías Ricardo Durango Padilla ${ }^{a} *(1)$, Luis Ricardo Oliveira Santos ${ }^{b}$, Diego Aleixo da Silva ${ }^{b}$, João \\ Lúcio de Barros ${ }^{c}$, Gabriela Bertoni Belini ${ }^{b}$, Fabio Minoru Yamaji ${ }^{b}$, Teófilo Miguel de Souzad, \\ Cristiane Inácio de Campos ${ }^{e}$ \\ ${ }^{a}$ Departamento de Engenharia Mecânica, Universidade Estadual Paulista Júlio de Mesquita Filho, Av. \\ Ariberto Pereira da Cunha, 333, 12516-410, Guaratinguetá, SP, Brasil \\ ${ }^{b}$ Departamento de Ciências Ambientais, Universidade Federal de São Carlos, 18052780 , Sorocaba, SP, \\ Brasil \\ 'Instituto Federal de Educação, Ciência e Tecnologia de São Paulo, 18202-000, Itapetininga, SP, Brasil \\ ${ }^{d}$ Departamento de Engenharia Elétrica, Universidade Estadual Paulista Júlio de Mesquita Filho, \\ 12516-410, Guaratinguetá, SP, Brasil \\ ${ }^{e}$ Universidade Estadual Paulista Júlio de Mesquita Filho, Campus de Itapeva. \\ 18409010, Itapeva, SP, Brasil
}

Received: June 08, 2019; Revised: November 22, 2019; Accepted: December 09, 2019

Eucalyptus bark is a waste generated in large volume and has been used as a source of energy. This study tries to use the Eucalyptus sp. bark as a source of raw material for the charcoal production and to study the influence of pyrolysis temperatures on charcoal properties. Charcoal was produced at different temperatures: 300,400 and $500^{\circ} \mathrm{C}$, and their properties were determined by proximate analysis, higher heating value and thermogravimetric analysis. It was observed that higher pyrolysis temperature resulted in increase of the fixed carbon content and higher heating value. In the thermogravimetry and derivative thermogravimetry curves it was possible to determine the differences in the thermal stability of charcoal produced. It can be concluded that the eucalyptus bark charcoal is an alternative for the energy reutilization of this waste and also can be used as charcoal for heating.

Keywords: TGA, Biomass energy, Wood residue, Solid Biofuel.

\section{Introduction}

Fossil fuels are the source of pollutants and greenhouse gases. Energy from non-renewable fuels can be partially, if not totally, replaced by renewable sources. This matrix exchange is the objective of several industrial sectors, as it entails financial and ecological gains. For example, the use of charcoal instead of coal in the iron and steel industry. Also, the use of biomass instead of gas or oil in boilers ${ }^{1}$.

Biomass is any organic matter that can be transformed into energy, either thermal, electrical or mechanical. The biomass origin can be urban, industrial, agricultural or forestry. All the forms in which biomass is obtained are seen as promising energy sources with potential for growth in the domestic and oversea market ${ }^{2}$.

Forest waste is a promising energy source for Brazil due to the large amount of forest plantations (7.8 million hectares) ${ }^{3}$. Canopies, branches, and bark of trees are forest exploitation wastes ${ }^{4}$. The use of eucalyptus and its residues for charcoal production have been studied ${ }^{5-6}$. Coal partial substitution by biomass is an attractive route to mitigate $\mathrm{CO}_{2}$

*e-mail: erdurango22@gmail.com emissions in the ironmaking process ${ }^{7}$. Compared to coal, biomass presents advantages, such as lower ash and Sulfur contents $^{8}$. In addition, the thermal treatments like torrefaction and carbonization can adjust the biomass volatile matter yield varying the maximum process temperature ${ }^{9}$. Thus, biomass research has received growing interest.

The objective of this study was to analyze the pyrolysis influence on charcoal properties, produced from eucalyptus bark at different temperatures.

\section{Material and Methods}

\subsection{Materials preparation and charcoal production}

The material used was Eucalyptus sp. bark, collected at a wood panel industry in the city of Salto, SP. The material after collection was weighed and dried using a Marconi MA 35 air circulation oven. A $100 \mathrm{~g}$ sample of dry material was milled using Marconi MA-340 Willey Knife Mill and separated for proximate analysis.

On the other hand, the dry bark was cut manually in $1 \times 4 \mathrm{~cm}$ sizes for the charcoal production (Figure 1B). 
Three pyrolysis temperatures were used: $300{ }^{\circ} \mathrm{C}, 400{ }^{\circ} \mathrm{C}$ and $500^{\circ} \mathrm{C}$. Approximately $20 \mathrm{~g}$ of the chopped bark was placed in a covered metal container. For the carbonization, a muffle furnace was used (Jung brand model 0212) at a heating rate of $20^{\circ} \mathrm{C} \cdot \mathrm{min}^{-1}$. The pyrolysis temperature was maintained for 3 hours under inert atmosphere (reduced oxygen atmosphere) ${ }^{10-11}$.

\subsection{Materials characterization.}

\subsubsection{Proximate analysis and higher heating value}

All analyzes for bark and charcoal (volatile matter, ash content and fixed carbon) were performed in triplicate. Approximately $1 \mathrm{~g}$ of the milled bark samples were placed in calcined crucibles. Then, they were heated in a muffle furnace (Jung brand, model 0212) at $950 \pm 25{ }^{\circ} \mathrm{C}$ for 7 minutes. After heating, the crucibles were cooled in a desiccator with silica gel for $1 \mathrm{~h}$ and weighed to determine the volatile matter. After weighing, the crucibles were taken back to the furnace for $6 \mathrm{~h}$ at $600 \pm 25^{\circ} \mathrm{C}$, cooled again in the desiccator, and reweighed to determine the ash content.

The same analyses (volatile matter, ash content and fixed carbon) were performed for the produced charcoal. The crucibles with approximately $1 \mathrm{~g}$ of dry charcoal sample were used. It was positioned at the edge of the preheated muffle at $950 \pm 25^{\circ} \mathrm{C}$, remaining in this position for 3 minutes (around $500{ }^{\circ} \mathrm{C}$ ), and then placed inside the muffle for 6 minutes with the door closed. After that, the crucibles were cooled in desiccator with silica gel for $1 \mathrm{~h}$ and weighed to determine the volatile matter. The same crucibles used for the volatile matter determination (with sample) were placed in the muffle furnace at $750^{\circ} \mathrm{C}$ for $6 \mathrm{~h}$. The crucibles were cooled in a desiccator for $1 \mathrm{~h}$ and weighed to determine the ash content. Fixed carbon is a value resulting from the sum of the ash content and volatile matter percentages subtracted from $100 \%$.

The higher heating value was determined for bark and charcoal sample in the bomb calorimeter brand IKA model C200.

All analyzes were conducted complying with the standards of the American Society for Testing and Materials ${ }^{12-16}$.

\subsubsection{Thermogravimetric analysis (TGA)}

Thermogravimetry (TG) and derivative thermogravimetry (DTG) were performed in the Perkin Elmer equipment, Pyris TGA 1 model. Approximately $21 \mathrm{mg}$ of the sample were used in a platinum pan under a high purity $(99.999 \%)$ nitrogen atmosphere with a flow rate of $20 \mathrm{ml} . \mathrm{min}^{-1}$. The heating rate was $20^{\circ} \mathrm{C} \cdot \mathrm{min}^{-1}$, temperature from 50 to $700{ }^{\circ} \mathrm{C}$.

\subsection{Statistical analyses}

The effects of experimental treatments were analyzed using software R version 2.11.1, by analysis of variance (ANOVA) and Tukey's multiple range tests ( $5 \%$ of probability).

\section{Results and Discussion}

\subsection{Proximate analysis and higher heating value}

Figure 1 shows the physical aspects of the eucalyptus bark samples and the respective charcoal. The samples were chopped and dried to make it possible the charcoal production in laboratory scale.

Table 1 shows the results of the proximate analysis and higher heating value (HHV) of eucalyptus bark and produced charcoal. Using biomass for energy purpose has some disadvantages such as high volatile matter and low fixed carbon content which were identified in the results of this study. The burning speed of pulverized biomass fuels is considerably higher than that of charcoal, and this behavior can be explained because the biomass has higher volatile matter compared to charcoal ${ }^{17}$.

The ash content of a charcoal and biomass fuels is also important. Generally, it varies from $0.5 \%$ to more than $5 \%$ depending on the species, the amount of bark and the presence of soil and sand in the sample. High levels of ash represent a decrease in energy potential and can cause corrosion in metal equipment. A good quality charcoal must have an ash content of less than $3 \%{ }^{18}$.

It can be seen in Table 1, that the ash content in the produced charcoal was higher than $3 \%$. This can be explained by a possible contamination of the bark (soil adhered) during harvesting ${ }^{19}$.

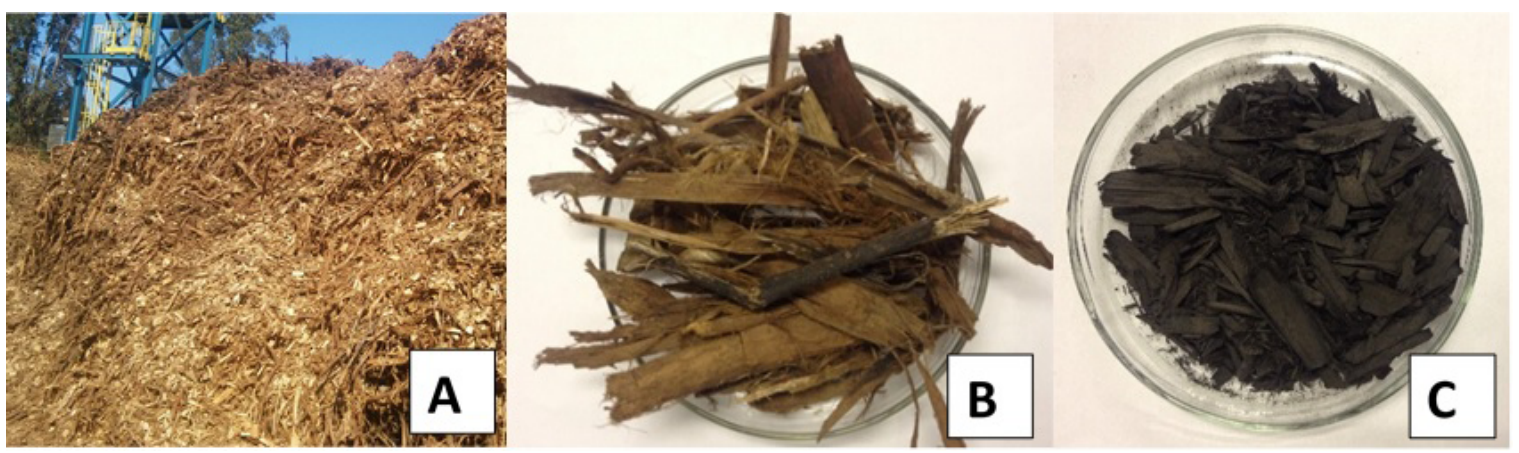

Figure 1. Investigated sample (A) eucalyptus bark (B) chopped bark (C) charcoal bark samples EB300. 
Table 1. Proximate analysis and HHV (dry basis).

\begin{tabular}{lcccc}
\hline Material & Volatile matter $(\%)$ & Ash $(\%)$ & Fixed carbon $(\%)$ & HHV $(\mathrm{MJ} / \mathrm{kg})$ \\
\hline eucalyptus Bark & $72.07 \pm 1.76 \mathrm{a}$ & $5.44 \pm 0,52 \mathrm{a}$ & $22.49 \pm 1.77 \mathrm{a}$ & $18.23 \pm 0.13 \mathrm{a}$ \\
EB300 & $44.79 \pm 0.79 \mathrm{~b}$ & $11.27 \pm 0,24 \mathrm{~b}$ & $43.94 \pm 1.03 \mathrm{~b}$ & $20.88 \pm 0.02 \mathrm{~b}$ \\
EB400 & $34.83 \pm 0.77 \mathrm{c}$ & $17.76 \pm 0,26 \mathrm{c}$ & $47.41 \pm 0.63 \mathrm{c}$ & $20.22 \pm 0.09 \mathrm{c}$ \\
EB500 & $24.07 \pm 0.21 \mathrm{~d}$ & $17.68 \pm 0,04 \mathrm{c}$ & $58.25 \pm 0.22 \mathrm{~d}$ & $22.94 \pm 0.11 \mathrm{~d}$ \\
\hline
\end{tabular}

Means followed by the same letter in the column are not statistically different by the test of Tukey at $5 \%$ level of probability

The optimum volatile matter of a "good-quality" charcoal depends on its use. For example, metallurgical grade charcoal should have a fixed-carbon content of 85$90 \%$, whereas charcoal intended for domestic cooking should have a minimum volatile matter content of $20-30 \%$, and a maximum of $40 \%{ }^{20}$. Although the charcoal produced in the three treatments $\left(300,400\right.$ and $\left.500{ }^{\circ} \mathrm{C}\right)$ did not meet the qualities of charcoal for metallurgy, they presented the necessary characteristics for domestic use.

The eucalyptus charcoal produced in the Sao Paulo state can be considered of good quality, with volatile matter, ash content, fixed carbon and HHV of $16.9 \% ; 1.20 \% ; 81.9 \%$ and $32.65 \mathrm{MJ} / \mathrm{kg}$, respectively ${ }^{21}$. The HHV of EB500 $(22.94 \mathrm{MJ} / \mathrm{kg}$ ) represents $72.2 \%$ when compared to the HHV of commercial eucalyptus charcoal $(32.65 \mathrm{MJ} / \mathrm{kg})$. Thus, bark charcoal (EB500) produced at a temperature of $500{ }^{\circ} \mathrm{C}$ exhibits potential for residential use.

\subsection{Thermogravimetric analysis (TGA)}

Biomass is composed mostly of cellulose, a polymer of glucose; hemicellulose, a complex polymer of which the main chain consists primarily of xylans or glucomannans; and lignin, a complex phenolic polymer, in addition to the main constituents, other non-structural (extractive) materials are present in fewer amounts ${ }^{22-24}$. Pyrolysis causes thermal degradation of these compounds and as a result, the biomass properties change significantly. Thermal degradation occurs in the order of hemicellulose $>$ cellulose $>$ lignin $^{23}$. Figure 2 presents the TG curves in (wt \%) for the materials.

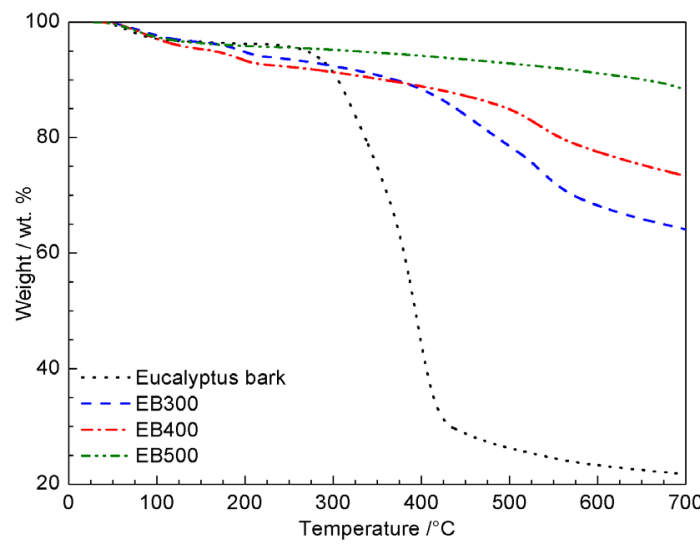

Figure 2. TG curves for eucalyptus bark and charcoal produced in nitrogen atmosphere and heating rate of $20^{\circ} \mathrm{C} \cdot \mathrm{min}^{-1}$.
In Figure 2, the difference in the thermal degradation between the eucalyptus bark and charcoal produced can be observed. Comparing the thermogravimetric curves it is observed that the pyrolysis process improves the thermal stability of the charcoal. As expected, the hemicelluloses were completely degraded in the charcoal, which can be proved by the absence of hemicelluloses peak in charcoal curves. According to Yang et al. ${ }^{25}$, the hemicelluloses decompose in the range from 220 to $315^{\circ} \mathrm{C}^{25}$. Also, it is possible to observe that the higher pyrolysis temperature, the lower the percentage of mass loss in an inert atmosphere. For example, at $700{ }^{\circ} \mathrm{C}$ the curves of charcoal showed low percentage of mass loss $35.9 \%, 26.6 \%$ and $11.8 \%$ for charcoal produced EB300, EB400 and EB500 respectively, when compared to eucalyptus bark $78.1 \%$. The curves showed that at $700{ }^{\circ} \mathrm{C}$ remained material are fixed carbon and ashes (same results of proximate analysis). Among the treatments (300, 400 and $500{ }^{\circ} \mathrm{C}$ ), it was found that EB500 was thermally more stable charcoal.

In Figure 3 the DTG curves (wt. \% / min) of the materials are shown. It is possible to observe the temperature with the peaks of the major mass losses and the maximum degradation rates of the materials. Table 2 presents the percentages of mass loss for the samples with the respective temperature and obtained residues (charcoal).

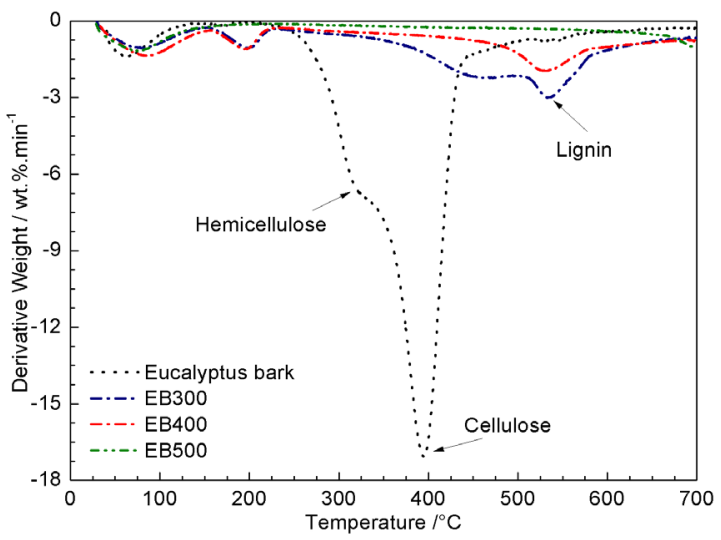

Figure 3. DTG curves for eucalyptus bark and charcoal produced.

In the DTG curves the initial mass loss at about $100^{\circ} \mathrm{C}$ was due to the water evaporation ${ }^{26}$. It was observed for EB300 and EB400 treatments another mass loss peak at 
Table 2. Data obtained from the TG/DTG curves for the produced eucalyptus bark and charcoals

\begin{tabular}{|c|c|c|c|c|c|}
\hline & & \multicolumn{4}{|c|}{ Material } \\
\hline & & eucalyptus bark & EB300 & EB400 & EB500 \\
\hline \multirow{2}{*}{$1^{\text {st }}$ step } & $\mathrm{T}_{\text {Peak }} \max$ & 319 & 457 & 530 & - \\
\hline & DTG $(\% / \mathrm{min})$ & 6.6 & 2.2 & 1.9 & - \\
\hline \multirow{2}{*}{$2^{\text {nd }}$ step } & $\mathrm{T}_{\text {Peak }} \max$ & 395 & 533 & - & - \\
\hline & DTG $(\% / \mathrm{min})$ & 16.9 & 2.9 & - & - \\
\hline \multirow{3}{*}{$3^{\text {rd }}$ step } & $\mathrm{T}_{\text {Peak }} \max$ & 541 & - & - & - \\
\hline & DTG $(\% / \mathrm{min})$ & 0.7 & - & - & - \\
\hline & Residue (\%) & 21.9 & 64.1 & 73.4 & 88.2 \\
\hline
\end{tabular}

*No detected

$197^{\circ} \mathrm{C}$. It must be due to a dehydration process involving the splitting off of a hydroxyl group and of a hydrogen between two hydroxyl groups to form water ${ }^{27}$.

The shoulder in the range from 230 to $360^{\circ} \mathrm{C}$ for eucalyptus bark DTG curves is due to the hemicellulose degradation. Another step was observed in the range from 360 to $430^{\circ} \mathrm{C}$, with the maximum mass loss rate $\left(16.9 \% \cdot \mathrm{min}^{-1}\right)$ at $395^{\circ} \mathrm{C}$, attributed to the cellulose degradation and part of the lignin. Finally, a slight loss of mass occurred in the range from 430 to $570^{\circ} \mathrm{C}$, with a maximum rate $0.7 \% / \mathrm{min}^{-1}$ at $541{ }^{\circ} \mathrm{C}$. The eucalyptus bark degradation after maximum mass loss rate at $395{ }^{\circ} \mathrm{C}$ indicates gradual lignin degradation into a carbon-rich residual solid, until it reaches approximately $21.9 \%$ weight at $700{ }^{\circ} \mathrm{C}^{23.27,28}$.

The pyrolysis temperature influenced the charcoal properties. DTG curves also showed that for charcoals the hemicellulose peaks disappeared, and the cellulose peak decreased dramatically, indicating thermal degradation of the hemicellulose and part of the cellulose during pyrolysis. When the pyrolysis temperature increased from 300 to $400^{\circ} \mathrm{C}$, the cellulose peak disappeared, which indicates that the cellulose was also degraded in EB400. In the treatment EB500 all the peaks almost disappeared indicating that the pyrolysis temperature used $\left(500^{\circ} \mathrm{C}\right)$ was sufficient to completely degrade the major biomass components.

The solid residues increased with the temperature charcoal production, for EB300, EB400 and EB500 treatments it was $64.1 \%, 73.4 \%$ and $88.2 \%$ respectively at $700{ }^{\circ} \mathrm{C}$. Comparing to proximate analysis, it was observed that higher pyrolysis temperature also resulted in increase of the fixed carbon content and HHV. Therefore, the difference between charcoals produced in different temperatures could be due to thermal degradation biomass components during pyrolysis, resulting in carbon-rich residual solid.

\section{Conclusion}

It is concluded that the eucalyptus bark can be used as a source of raw material for the charcoal production. Charcoal obtained from eucalyptus bark has enough quality to be applied for heating or domestic use. The DTG curve showed that pyrolysis temperature causes thermal degradation of the biomass components (hemicellulose, cellulose and lignin) resulting in properties changes as increase of the fixed carbon content and HHV.

\section{Acknowledgments}

The authors thank the research group Biomass and Bioenergy of UFSCar - Sorocaba campus, for the support provided to the development of this study. This study was partially financed by Coordenação de Aperfeiçoamento de Pessoal de Nível Superior - Brasil (CAPES) - Finance Code 001

\section{References}

1. Goldemberg J, Lucon O. Energia e meio ambiente no Brasil. Estudos Avançados. 2007;21(59):7-20.

2. Kelman J, Santana EA, Saraiva JCD, Senna JGSM, Rufino RD. Atlas de Energia Elétrica do Brasil: Biomassa. $3^{\text {a }}$ ed. Brasília: ANEEL; 2008.

3. Indústria Brasileira de Árvores (IBÁ). Da garantia de suprimento de matéria-prima para todos os usos da madeira - atuais de potenciais - a uma nova economia de baixo carbono, a solução passa pelas florestas plantadas. São Paulo: IBÁ; 2016; [access in 2019 may 28]. Available from: https://goo.gl/frrRkh

4. Brito JO, Barrichelo LEG, Couto HTZ, Fazzio ECM, Corradini L, Carrara MA, et al. Avaliação das características dos resíduos de exploração florestal do eucalipto para fins energéticos. IPEF - Circular Técnica. 1979;1(62):1-7.

5. Trugilho PF, Lima JT, Mori FA, Lino AL. Avaliação de clones de Eucalyptus para produção de carvão vegetal. Cerne. 2001;7(2):104-114.

6. Santiago AR, Andrade AM. Carbonização de resíduos do processamento mecânico da madeira de eucalipto. Ciência Florestal. 2005;15(1):1-7.

7. Feliciano-Bruzual C. Charcoal injection in blast furnaces (Bio$\mathrm{PCI}$ ): $\mathrm{CO}_{2}$ reduction potential and economic prospects. Journal of Materials Research and Technology. 2014;3(3):233-243.

8. Suopajärvi H, Pongrácz E, Fabritius T. The potential of using biomass-based reducing agents in the blast furnace: a review 
of thermochemical conversion technologies and assessments related to sustainability. Renewable and Sustainable Energy Reviews. 2013;25(45):511-528.

9. Pohlmann JG, Borrego AG, Osório E, Diez MA, Vilela ACF. Combustion of eucalyptus charcoals and coals of similar volatile yields aiming at blast furnace injection in a $\mathrm{CO} 2$ mitigation environment. Journal of Cleaner Production. 2016;129(1):1-11.

10. Padilla ERD, Nakashima GT, Hansted ALS, Santos LRO, Barros JL, Conti AC, et al. Thermogravimetric and FTIR analyzes of corn cob pyrolysis. Quimica Nova. 2019;42(5):566-569.

11. Santos LB, Striebeck MV, Crespi MS, Ribeiro CA, Julio M. Characterization of biochar of pine pellet. Journal of Thermal Analysis and Calorimetry. 2015;122(1):21-32.

12. American Society of Testing Materials (ASTM). E871-13 Standard test method for moisture analysis of particulate wood fuels. West Conshohocken, PA: ASTM International; 2013.

13. American Society of Testing Materials (ASTM). E872-13 - Standard test method for volatile matter in the analysis of particulate wood fuels. West Conshohocken, PA: ASTM International; 2013.

14. American Society of Testing Materials (ASTM). D1102-13 Standard test method for ash in wood. West Conshohocken, PA: ASTM International; 2013.

15. American Society of Testing Materials (ASTM). D1762-13 Standard test method for chemical analysis of wood charcoal. West Conshohocken, PA: ASTM International; 2013.

16. American Society of Testing Materials (ASTM). E711-04 Standard test method for gross calorific value of refuse-derived fuel by the bomb calorimeter. West Conshohocken, PA: ASTM International; 2004.

17. Demirbas A. Combustion characteristics of different biomass fuels. Progress in Energy and Combustion Science. 2004;30(2):219-230.

18. Pereira JCD, Sturion JA, Higa AR, Higa RCV, Shimizu JY. Características da madeira de algumas espécies de eucalipto plantadas no Brasil. Colombo: EMBRAPA - Florestas; 2000; [access in 2019 may 28]. Available from: https://www.infoteca. cnptia.embrapa.br/bitstream/doc/297469/1/doc38.pdf

19. Hansted ALS, Cacuro TA, Nakashima GT, Costa VE, Yamamoto $\mathrm{H}$, Yamaji FM. Use of a lignocellulosic residue as solid fuel: The effect of ash content in the energy potential. Industrial Crops and Products. 2018;116(1):209-214.

20. Antal MJ, Croiset E, Dai X, Almeida C, Mok WSL, Norberg $\mathrm{N}$, et al. High-yield biomass charcoal. Energy and Fuels. 1996;10(3):652-658.

21. Dias Júnior AF, Brito JO, Andrade CR. Granulometric influence on the combustion of charcoal for barbecue1. Revista Arvore. 2015;39(6):1127-1133.

22. Bernabé GA, Kobelnik M, Almeida S, Ribeiro CA, Crespi MS Thermal behavior of lignin and cellulose from waste composting process. Journal of Thermal Analysis and Calorimetry. 2013;111(1):589-595.

23. Demirbas A, Arin G. An overview of biomass pyrolysis. Energy Sources. 2002;24(5):471-482.

24. Manzato L, Rabelo LCA, Souza SM, Silva CG, Sanches EA, Rabelo D, et al. New approach for extraction of cellulose from tucumã's endocarp and its structural characterization. Journal of Molecular Structure. 2017;1143(5):229-234.

25. Yang H, Yan R, Chen H, Lee DH, Zheng C. Characteristics of hemicellulose, cellulose and lignin pyrolysis. Fuel. 2007;86(1213):1781-1788

26. Guimarães JL, Frollini E, Silva CG, Wypych F, Satyanarayana KG. Characterization of banana, sugarcane bagasse and sponge gourd fibers of Brazil. Industrial Crops and Products. 2009;30(3):407-415.

27. Ramiah MV. Thermogravimetric and differential thermal analysis of cellulose, hemicellulose, and lignin. Journal of Applied Polymer Science. 1970;14(5):1323-1337.

28. Chen WH, Kuo PC. A study on torrefaction of various biomass materials and its impact on lignocellulosic structure simulated by a thermogravimetry. Energy. 2010;35(6):2580-2586. 